\title{
Seks i seksualność w perspektywie nauk społecznych — wprowadzenie
}

\author{
DOI: 10.19195/2083-7763.8.1
}

\section{Seksualność w naukach społecznych i socjologii}

Mniej więcej od końca ubiegłego wieku pojawia się coraz więcej publikacji i badań dotyczących seksualności, cielesności, intymności oraz rozmaitych aspektów erotyki jako pewnych form społecznych, fenomenów czy procesów mających miejsce w nowoczesnych społeczeństwach. Jeszcze do niedawna taka problematyka była wiązana z perspektywą antropologiczną lub z marginalnymi nurtami socjologicznymi. Obecnie tematyka seksualności pojawia się w głównym nurcie socjologii i jest analizowana $\mathrm{z}$ różnych perspektyw teoretycznych przez uznanych socjologów.

Być może należałoby omówić i pokazać przede wszystkim zasadę konstrukcji seksu oraz seksualności jako problemu społecznego i socjologicznego poprzez wyraźne rozróżnienie perspektyw: antropologicznej, socjologicznej i psychologii ewolucyjnej. Dostrzeglibyśmy wtedy jedną z zasadniczych różnic. Otóż antropologowie kulturowi, w przeciwieństwie do socjologów, względnie często opisywali seksualność czy intymność jako jeden z integralnych elementów systemu społeczno-kulturowego. Wystarczy przywołać klasyczne prace Bronisława Malinowskiego $^{1}$ czy Margaret Mead ${ }^{2}$. Również psychologia ewolucyjna czyniła seksualność integralnym elementem analizy psychiki człowieka. Nie będziemy tu szczegółowo omawiać podejścia Zygmunta Freuda i jego kontynuatorów, ale raz jeszcze warto podkreślić, jak istotne było pojawienie się tego nurtu dociekań. W latach

${ }^{1}$ Należy tu przywołać klasyczne prace: The Sexual Life of Savages in North-Western Melanesia, London 1929; Życie seksualne dzikich w pótnocno-zachodniej Melanezji: Miłość, małżeństwo i życie rodzinne u krajowców z wysp Trobriandzkich Brytyjskiej Nowej Gwinei, Warszawa 1938; Sex and Repression in Savage Society, London 1937; Seks i sttumienie w społeczności dzikich, Warszawa 1987.

2 M. Mead, Sex and Temperament in Three Primitive Societies, New York 1937. Ciekawym i dobrym przykładem takiej historyczno-antropologicznej analizy w nowszej literaturze może być pozycja Wolfganga Reinharda: Życie po europejsku. Od czasów najdawniejszych do wspótczesności, przeł. J. Antkowiak, Warszawa 2009. 
siedemdziesiątych ubiegłego wieku Edward O. Wilson stworzył nowy paradygmat, który określił mianem socjobiologii. Jest on skoncentrowany na próbach wyjaśniania zjawisk społecznych i kulturowych za pomocą mechanizmów biologicznych, porównywania ludzkich społeczeństw do społeczności zwierzęcych. Zwolennicy tego nurtu - dokonujący świadomej fuzji elementów psychologii, socjologii historycznej (czy raczej socjologii archeologicznej, jeżeli możemy sobie pozwolić na taką ekstrawagancję terminologiczną) z postdarwinowską teorią ewolucji - używają już innej etykiety: psychologia ewolucyjna ${ }^{3}$. To w niej znajdujemy (hipo)tezy doszukujące się źródeł kultury symbolicznej (sztuki, poezji, muzyki) i zdolności symbolicznej ekspresji w instynktach, popędach seksualnych. Kultura, szczególnie pierwotne kultury homo sapiens, jest odzwierciedleniem mechanizmów już nie tylko płciowego, lecz także seksualnego doboru.

Sama socjologia oczywiście nie była całkowicie wolna od tego typu refleksji, choć zainteresowania o wiele bardziej koncentrowały się wokół problemów makrostrukturalnych. W momencie kształtowania się socjologii humanistycznej pojawiają się wątki analizujące erotyczność i seksualność jako zjawiska nie tylko kulturowe, ale i społeczne właśnie. Georg Simmel w sposób charakterystyczny dla swojego impresjonizmu socjologicznego wskazuje tropy analizy kokieterii jako formy gry towarzyskiej odrywającej się od erotyczności, polegającej na wzajemnym „podprowadzaniu” do granic erotycznego zaangażowania bez wkraczania w realizację ryzykownych relacji. To gra uciekająca się do powstrzymywania się przed osiągnięciem oczywistego celu, toczona dla podniecającej narracji, zarazem dalekiej od spełnienia swych treści ${ }^{4}$. Bardzo zaawansowaną analizę historyczną zjawiska seksualności przestawił Norbert Elias w swoim opus magnum z $1939 \mathrm{roku}^{5}$. Postawy wobec seksualności ilustrowały proces „cywilizacji”. Na podstawie podręczników edukujących chłopców w XV/XVI wieku (Erazm z Rotterdamu) i dziewczęta w XIX wieku (Georg Wilhelm von Raumer) opisywał on poczucie wstydu otaczające seksualność, wzmagające się w procesie cywilizacji. Pokazywał coraz dalej posunięte uintymnianie funkcji fizjologicznych,

${ }^{3}$ Literatura z zakresu psychologii ewolucyjnej jest niezmiernie bogata i nie sposób przywołać tutaj nawet tych najważniejszych pozycji. Możemy podać przykłady, które z naszego punktu widzenia wypada potraktować jako znaczące: S. Pinker, The Blank Slate: The Modern Denial of Human Nature, New York 2002; idem, Tabula rasa. Spory o nature ludzka, Sopot 2005; G. Miller, The Mating Mind. How Sexual Choice Shaped the Evolution of Human Nature, London 2000 [Umyst w zalotach. Jak wybory seksualne kształtowaly naturę człowieka, Poznań 2004]; idem, Spent. Sex, Evolution and the Secrets of Consumerism, London 2009 [Teoria szpanu. Seks, ewolucja i zachowania klienta, Warszawa 2010]. Bardzo dobrą ilustracją humanizowania się psychologii ewolucyjnej jest pozycja Cacildy Jetha i Christophera Ryana Na początku był seks. Prehistoryczne źródła nowoczesnej seksualności, przeł. A. Patrykowska, Warszawa 2012.

${ }^{4}$ G. Simmel, Socjologia, przeł. M. Łukasiewicz, Warszawa 2005, s. 34-44; idem, Psychologia kokieterii, [w:] idem, Most i drzwi, przeł. M. Łukasiewicz, Warszawa 2006.

${ }^{5}$ N. Elias, Ewolucja postawy wobec stosunków seksualnych, [w:] idem, Przemiany obyczajów w cywilizacji Zachodu, przeł. T. Zabłudowski, K. Makarewicz, Warszawa 1980. 
izolowanie ich $\mathrm{w}$ specjalnych enklawach i usuwanie $\mathrm{z}$ pola widzenia. Odrębny i specyficzny program socjologii Michela Foucaulta koncentruje się na władzywiedzy opisanej w Historii seksualności ${ }^{6}$. Wyróżnia on dwie formy świadomości i wiedzy - „procedury produkujące prawdę o seksie" - ars erotica i scientia sexualis. Pierwsza, typowa dla cywilizacji starożytnych i wschodnich, jest oparta na zasadzie rozkoszy i społecznym doświadczeniu, które w sposób niejawny („wiedza nieodzownie tajemna”) kształtowały wzory zachowań społecznych, co stawało się sztuką samodoskonalenia i sposobem wtajemniczenia w sens uspołecznienia. Druga, typowa dla nowożytnej cywilizacji zachodniej, jest praktyką dyskursywną, skupioną na pogłębianiu wiedzy o charakterze naukowym, przy czym owo zgłębianie produkowało i produkuje procedury poznawcze podporządkowane władzy-wiedzy. Foucault pisze, że dyskurs na temat seksu, który sprzęga się ze zmedykalizowanym dyskursem naukowym, częściej skrywa prawdę o seksie („dyskurs uczonych i teoretyków miałby wciąż skrywać swą problematykę"7). Postmodernistyczna perspektywa, choć nader często zawiła w narracji, w kwestii seksualności wyraża prostą prawdę, często przez nas doświadczaną, że seksualność może stać się samoistnym elementem nie tylko kultury, lecz także naszego prywatnego życia i sztuczną fasadą zniewolenia przez inne mechanizmy społeczne (np. konsumpcję). Jean Baudrillard ${ }^{8}$ stworzył oryginalną koncepcję symulakrów (symulakrum, symulacji). Znaki, symbole (elementy kultury symbolicznej) w wysoce zmediatyzowanej ponowoczesności tracą swoją referencyjność i odrywają się od rzeczywistości. Pojawia się coraz więcej znaków i symboli odnoszących się nie do rzeczywistości, lecz do innych, już istniejących znaków lub symboli. Tworzy się w ten sposób hiperrzeczywistość - rodzaj doświadczanej rzeczywistości symboli bez odniesienia do „prawdziwej” rzeczywistości. Baudrillard ilustruje swoją teorię przykładami Disneylandu czy Las Vegas. Są to przestrzenie wypełnione „sztucznymi” znakami, które stają się dla nas „prawdziwą” rzeczywistością, gdyż jedyną doświadczaną. Uczestnictwo w niej podlega zasadzie szczęścia i rozkoszy, a właściwie przymusowi rozkoszy, by intensyfikować doznanie rzeczywistości i jej przeżywanie. Pornografia jest także doskonałym przykładem hiperrzeczywistości i symulakrów. Świat porno jest wypełniony „sztucznymi” znakami, zwielokrotnionymi i stale podlegającymi samoreferencji. Jednocześnie świat porno wydaje się doświadczaną przez nas rzeczywistością, ponieważ to ona kreuje wzory naszego

${ }^{6}$ M. Foucault, Historia seksualności, przeł. B. Banasik, T. Komendant, K. Matuszewski, Gdańsk 2010, s. 43-56.

7 Ibidem, s. 43.

${ }^{8}$ J. Baudrillard - trudno będzie wskazać bezpośrednie analizy dotyczące seksualności. Należy się odwołać raczej do pośrednich śladów - ilustracji czy barwnych sugestii zaledwie. Te tropy są obecne np. w takich publikacjach, jak Symulakry i symulacja, przeł. S. Królak, Warszawa 2005; O uwodzeniu, przeł. J. Margański, Warszawa 2005; Społeczeństwo konsumpcyjne. Jego mity i struktury, przeł. S. Królak, Warszawa 2006. 
działania. Seksualność staje się zatem sztuczna i wymuszona, coraz dalsza od erotyzmu i mechanizmów uwodzenia, stechnicyzowana, choć dla nas jedyna.

Wszystkie te programy socjologiczne tworzone były na obrzeżach głównych nurtów socjologii. Ich twórcy natomiast sami często byli outsiderami i choć ich kompetencje nigdy nie były podważane, prace były odkrywane niekiedy po latach.

Od lat dziewięćdziesiątych seksualność, relacje intymne, erotyzm stają się tematem podejmowanym przez czołowych i znaczących socjologów i można uznać, że powoli dokonuje się ewidentny zwrot $\mathrm{w}$ traktowaniu tej problematyki od marginalizacji do włączenia w główny nurt. Właściwie nie sposób wskazać wszystkich prac, dlatego arbitralnie ograniczymy się do hasłowego wymienienia według nas najważniejszych (co oznacza również znacząco obecnych w literaturze polskiej i powszechnie cytowanych). Jedna z ważniejszych i często przywoływanych prac traktuje niebezpośrednio o społecznym wytwarzaniu seksualności. Pierre Bourdieau analizuje przede wszystkim podstawowe, by nie powiedzieć prymarne, formy nierówności społecznej w obrębie binarności płciowej, które w efekcie w społecznościach tradycyjnych przybierają formę męskiej dominacji $^{9}$ determinującej cały porządek społeczny i produkującej habitusy jednostek. Anthony Giddens ujawnia mechanizmy konstrukcji ideologicznych ujmujących seksualność w społeczno-historyczne ramy, wytwarzających erotyzm jako miłość romantyczną w XIX wieku oraz czystą relację pod koniec XX wieku' ${ }^{10}$. Jean-Claude Kaufmann zadaje pytanie, czy małżeńskie szczęście w naszych społeczeństwach jest możliwe, a w poszukiwaniu „miłości” sięga do źródeł historyczno-kulturowo-socjologicznych, przede wszystkim europejskiej kultury ${ }^{11}$. Niklas Luhamnn ujmuje miłość jako proces semantycznego kodowania komunikacji społecznej, odzwierciedlający dominujące wzory relacji społecznych od początku nowoczesności, także w europejskich społeczeństwach ${ }^{12}$. Przegląd kultury masowej i popularnej, w której seks staje się jednym z motywów przewodnich, skłoniło Briana McNaira do sformułowania tezy o seksualizacji i pornografizacji kultury, i paradoksalnie jednocześnie jej demokratyzacji ${ }^{13}$.

Polską socjologię w największym skrócie można zobrazować klamrą publikacji. Z jednej strony jeszcze w 1948 roku (późno czy wcześnie w skali istnienia polskiej socjologii - trudno rozstrzygnąć) pojawia się swoisty fenomen - Socjologia kobiety ${ }^{14}$ Stanisława Szantera z przedmową Jana S. Bystronia. Publikacja

9 P. Bourdieau, Męska dominacja, przeł. L. Kopciewicz, Warszawa 2004.

10 A. Giddens, Przemiany intymności, przeł. A. Szulżycka, Warszawa 2006.

11 J.-C. Kaufmann, Niezwykła historia szczęśliwej miłości, przeł. A. Kapciak, Warszawa 2012.

12 N. Luhmann, Semantyka miłości. O kodowaniu intymności, przeł. J. Łoziński, Warszawa 2003. O wykorzystaniu teorii Luhamnna w analizie artefaktów kulturowych zob. P. Niedopytalska, P. Czajkowski, Paradoks Greya. O normatywnych i nienormatywnych wzorach kobiecej seksualności, w tomie.

13 B. McNair, Seks, demokratyzacja pożądania i media, czyli kultura obnażania, przeł. E. Klekot, Warszawa 2004.

14 S. Szanter, Socjologia kobiety, Warszawa 1948. 
jest przede wszystkim świadectwem stanu ówczesnej świadomości; ujmuje pozycję społeczną kobiety z punktu widzenia determinizmu biologicznego, królującego w świadomości społecznej. Szanter rysuje panoramę świadomości społecznej, w której funkcje społeczne kobiety zależą od jej funkcji płciowych. Niewątpliwie jest to praca zasługująca na uwagę historyka dyscypliny i socjologów wiedzy. $\mathrm{Z}$ drugiej strony mamy już nam współczesne prace Tomasza Szlendaka ${ }^{15}$, który może być uznany za prekursora nowego podejścia do tematyki seksualności i erotyki dzięki sięganiu po najnowsze osiągnięcia nauki o ewolucji i odwoływaniu się do klasycznych badań socjologicznych nad religijnością i seksualnością. Praca Lecha M. Nijakowskiego ${ }^{16}$ o pornografii jest niemalże monumentalną analizą historii zjawiska i przeglądem nurtów marginalnych, które w tym potężnym biznesie łamią tabu z naddatkiem. Studia przedstawiają także strukturalny aspekt funkcjonalności i dysfunkcjonalności zjawiska. Jacek Kochanowski ${ }^{17} \mathrm{z}$ kolei koncentruje się na tzw. marginesach wytwarzania seksualności - jak poza głównym nurtem filozofii, polityki, kultury, emocji, cielesności czy wreszcie socjologii funkcjonuje seksualność i co ona oznacza ${ }^{18}$.

\section{Od esencjalizmu do konstruktywizmu}

Rozwój i pogłębianie refleksji nad ludzką seksualnością prowadziły do odkrywania ogromnej różnorodności jej form. Dostrzeżenie jej wyzwoliło między innymi proces przejścia od perspektywy esencjalistycznej do perspektywy konstrukcjonistycznej. Podejście esencjalistyczne opiera się na przekonaniu, że pewne zjawiska związane z funkcjonowaniem człowieka są naturalne, nieuniknione, uniwersalne i zdeterminowane biologicznie. Esencjalizm ujmuje seksualność jako zjawisko czysto biologiczne, ściśle powiązane z funkcją reprodukcji gatunkowej. Z kolei kluczowym założeniem paradygmatu konstrukcjonistycznego jest sformułowana przez Petera Bergera i Thomasa Luckmanna teza o społecznym konstruowaniu rzeczywistości ${ }^{19}$. Wywodzące się z tej koncepcji przeświadczenie o społecznym charakterze seksualności prowadzi do wniosku, iż: „[s]eksualność

15 T. Szlendak, Architektonika romansu, Warszawa 2002; idem, Supermarketyzacja. Religia i obyczaje seksualne młodzieży w kulturze konsumpcyjnej, Wrocław 2004; idem, Leniwe maskotki, rekiny na smyczy. W co kultura konsumpcyjna przemienia mężczyzn i kobiety, Warszawa 2005.

16 L.M. Nijakowski, Pornografia. Historia, znaczenie, gatunki, Warszawa 2010.

17 J. Kochanowski, Socjologia seksualności. Marginesy, Warszawa 2013.

18 Oczywiście w polskiej socjologii pojawiają się także inne prace, które w bezpośredni lub pośredni sposób nawiązują do tematyki szeroko rozumianego społecznego wytwarzania seksualności. By wymienić tylko kilka: D. Majka-Rostek, Związki homoseksualne. Studium socjologiczne, Warszawa 2008; D. Duch-Krzystoszek, Małżeństwo, seks, prokreacja, Warszawa 1998; H. Jakubowska, Socjologia ciała, Poznań 2009; E. Banaszak, Eksperiencje nagości, Warszawa 2017; J.M. Kurczewski et al., Praktyki cielesne, Warszawa 2006.

19 P. Berger, T. Luckmann, Społeczne tworzenie rzeczywistości, przeł. J. Niżnik, Warszawa 2010. 
jest tak samo ludzkim produktem, jak diety, metody transportu, system etykiety, formy pracy, typ rozrywki, proces produkcji i sposoby opresji" 20 . W tej perspektywie seksualność jest kreowana przez kulturę - przez definiowanie pewnych zachowań i relacji jako „seksualne” oraz przez nabywanie tych definicji czy skryptów przez członków społeczeństwa ${ }^{21}$. Steven Seidman pisze:

Rodzimy się obdarzeni ciałem, ale to społeczeństwo określa, które jego części i jakie przyjemności i zachowania mają charakter seksualny. Również dzielenie zachowań seksualnych na dobre i złe lub dopuszczalne i niedozwolone traktuje się obecnie jako wytwór władzy społecznej: dominujące normy seksualne są odzwierciedleniem przekonań dominujących grup społecznych ${ }^{22}$.

Ken Plummer twierdzi, że tzw. zwrot konstrukcjonistyczny był kluczowym punktem współczesnego podejścia nauk społecznych do seksualności ${ }^{23}$. Konstrukcjoniści zaczęli dostrzegać i ukazywać, jak seksualność człowieka jest zawsze powiązana z warunkami społecznymi i kształtowana przez czynniki ekonomiczne, religijne, polityczne, rodzinne itp. Nie jest ona zjawiskiem uniwersalnym - jest zmienna kulturowo i historycznie, stanowi wynik ciągłych negocjacji i konfliktów pomiędzy tymi, którzy mają władzę definiowania, regulowania i kontrolowania, a tymi, którzy opierają się tym mechanizmom ${ }^{24}$. Na bazie konstrukcjonistycznych rozważań wyrosły koncepcje negujące istnienie ścisłych powiązań pomiędzy płcią biologiczną, płcią społeczno-kulturową oraz seksualnością. Esencjalistycznie ujmowane powiązania tworzyły „układ binarny” - heteroseksualne kobiece kobiety oraz heteroseksualni męscy mężczyźni. Zmiana przynajmniej jednego elementu każdego z dwóch modeli pociągała za sobą konieczność zmiany postrzegania pozostałych części składowych. Przykładowo, kobieta homoseksualna nie tylko nie mogła być postrzegana jako kobieca, lecz traktowana była także jako nie-kobieta, osoba np. niezdolna do macierzyństwa. Dekonstrukcje płci (biologia, fizjologia), gender (znaczenia, role i pozycje społeczne) i seksualności (pożądanie, seksualne preferencje, orientacja) odkryły wiele kategorii społecznych, tożsamości, doświadczeń i praktyk wykraczających poza ten binaryzm ${ }^{25}$. Coraz wyraźniejsza różnorodność nie wyklucza seksualnych kategoryzacji i stratyfikacji, przeciwnie - idzie z nimi w parze. Społecznie konstruowana seksualność jest narzędziem przemocy normatywnej. O współczesnych hierarchicznych drabinach seksualnych Gayle Rubin pisze:

${ }^{20}$ G.S. Rubin, Rozmyślając o seksie: zapiski $w$ sprawie radykalnej teorii polityki seksualności, „Lewą Nogą" 2004, nr 16, s. 176.

21 J.D. DeLamater, J.S. Hyde, Essentialism vs. social constructionism in the study of human sexuality, „Journal of Sex Research” 35, 1998, nr 1, s. 10-18.

22 S. Seidman, Społeczne tworzenie seksualności, przeł. P. Tomanek, Warszawa 2012, s. 83.

${ }^{23}$ K. Plummer, Queers, bodies and post-modern sexualities: A note on revisiting the "sexual”, "Qualitative Sociology" 26, 2003, nr 4, s. 515-530.

24 J. Weeks, Sexuality, London 1986.

25 J. Lorber, Beyond the binaries: Depolarizing the categories of sex, sexuality, and gender, „Sociological Inquiry" 66, 1996, s. 143-160. 
Na szczycie erotycznej piramidy znajdują się jednostki zamężne, heteroseksualne, posiadające dzieci. Poniżej znajdują się niezamężne, monogamiczne pary heteroseksualne, a z nimi większość innych heteroseksualistów [...]. Stabilne, długotrwałe pary gejowskie i lesbijskie znajdują się na granicy akceptacji, ale barowe lesby czy lubieżni geje już poniżej wszystkich grup, na samym dnie piramidy. Najbardziej znienawidzone seksualnie kasty to w chwili obecnej transseksualiści, transwestyci, fetyszyści, sadomasochiści, prostytutki i gwiazdy porno oraz najbardziej podrzędni z tych wszystkich ci, których erotyzm przekracza pokoleniowe granice ${ }^{26}$.

System seksualnej opresji jest połączony z innymi wymiarami stratyfikacji. Położenie klasowe, rasowe lub etniczne może albo wzmagać, albo minimalizować jego oddziaływanie. Tak jak inne hierarchie społeczne, podlega on historycznym modyfikacjom - forma seksualności całkowicie w danym momencie nieakceptowana może przesunąć się na wyższe, choć na pewno nie na dominujące, pozycje.

Tendencje do odchodzenia od perspektywy esencjalistycznej w ujmowaniu seksualności przez przedstawicieli nauk społecznych można zilustrować na przykładzie ewolucji podejścia naukowego wobec homoseksualizmu. Począwszy od XIX wieku, zjawiskiem tym interesowali się głównie przedstawiciele medycyny, kryminologii oraz psychoanalizy. Dla reprezentantów nauk społecznych punktem zwrotnym było opublikowanie w 1948 roku studium postaw i zachowań seksualnych, znanego dziś jako „raport Kinseya”27. Przedstawienie orientacji seksualnej człowieka na siedmiopunktowej skali zanegowało jednoznaczny, dychotomiczny podział ludzi na homoseksualistów i heteroseksualistów. Mimo to pierwszy nurt zainteresowań socjologów tymi zjawiskami wyraźnie pozostawał pod wpływem etiologicznych koncepcji dewiacji i patologii. $Z$ czasem zaczęto przyjmować perspektywę teorii reakcji społecznej. Nie porzucając esencjalistycznych założeń na temat istnienia pewnych uniwersalnych cech, mających charakteryzować wszystkie osoby homoseksualne, zastanawiano się nad rolą stygmatyzacji i naznaczania społecznego w kreowaniu kategorii seksualnych ${ }^{28}$. Konsekwencją było stopniowe odchodzenie od esencjalistycznego spojrzenia na homoseksualizm jako na zuniformizowane, jednolite i ahistoryczne zjawisko. W 1968 roku ukazal się znaczący dla owego procesu artykuł Mary Macintosh, zawierający propozycję, aby homoseksualizm ujmować nie jako stan czy kondycję specyficznej kategorii osób, ale jako rolę społeczną będącą wytworem historycznym konkretnych społeczeństw ${ }^{29}$. Przekonanie o społecznej konstrukcji homoseksualizmu stało się podstawą prac M. Foucaulta - autora klasycznej już dziś tezy o zastąpieniu sodomity przez homoseksualistę - kategorię stworzoną na bazie związku władzy i wiedzy, służącą zwiększeniu kontroli społecznej i ochronie dyskursywnie zde-

${ }^{26}$ G.S. Rubin, op. cit., s. 178.

27 A.C. Kinsey, W.B. Pomeroy, C.E. Martin, Sexual Behavior in the Human Male, Philadelphia 1948.

28 Zob. np. J.I. Kitsuse, Societal reaction to deviant behavior: Problems of theory and method, „Social Problems” 9, 1962, s. 247-256.

${ }^{29}$ M. Macintosh, The homosexual role, „Social Problems” 1968, nr 16/2. 
finiowanego ładu normatywnego ${ }^{30}$. Pod koniec lat osiemdziesiątych pojawił się kolejny nurt w podejściu do homoseksualizmu — perspektywa queer. Z jednej strony wyrastała $\mathrm{z}$ konstrukcjonizmu, podzielając kluczowe dla niego przeświadczenie o społecznym wpływie na generowanie znaczeń związanych $\mathrm{z}$ seksualnością, z drugiej zaś kontestowała etniczno-tożsamościowe podejście do homoseksualizmu. Podstawowe elementy tej perspektywy to: postrzeganie seksualności w kontekście władzy; problematyzacja kategorii seksualnych i genderowych jako niewystarczających, nierozłącznych, a przede wszystkim opresyjnych; odrzucenie strategii praw obywatelskich na rzecz strategii transgresji i oporu wobec asymilacji; włączanie do akademickich analiz obszarów dotąd nieujmowanych w kontekście seksualności ${ }^{31}$. Na gruncie teorii queer wyrosło też wiele koncepcji analiz heteronormatywności - zestawu wzorów i praktyk społecznych, legitymizujących i uprzywilejowujących heteroseksualność jako właściwą, naturalną, normalną oraz niewymagającą żadnych wyjaśnień formę ludzkiego funkcjonowania ${ }^{32}$.

\section{Unaukowienie seksualności}

Nauki społeczne explicite lub implicite wywołują lub wręcz wymuszają refleksje na temat ludzkiej seksualności i seksu. Uświadamiają, że nie ma jednej seksualności i jednego sposobu uprawiania seksu; zamiast tego są wielorakie formy odzwierciedlone w dyskursywnej mnogości. Ale to badania Alfreda Charlesa Kinseya - profesora entomologii i zoologii - są powszechnie wskazywane jako początek poważnego naukowego zainteresowania seksualnością człowieka, a przy okazji także społecznego wpływu na badania naukowe oraz oddziaływania tych badań na społeczeństwo. Warto zatem mieć w pamięci, że dominująca perspektywa percypowania i traktowania tej sfery ludzkiego życia w nowoczesnych społeczeństwach przez długi czas była tworzona przede wszystkim przez medyków. Dyskurs medyczny wykreował własne sposoby kategoryzowania, diagnozowania, leczenia i zarazem patologizowania życia seksualnego człowieka. To, co niegdyś było grzeszne, stało się perwersyjne, dewiacyjne, zboczone lub było (czasem nadal jest) umiejscawiane we wszystkich tych kategoriach naraz. $\mathrm{W}$ dużym skrócie: wieczne potępienie bądź pokutną pielgrzymkę uzupełniły albo zastąpiły jednostka chorobowa i terapia naprawcza. Apogeum tej trajektorii należało do „konstruktorów” psychopatologii, w rodzaju Samuela Augusta Tissota lub Friedricha Eduarda Bilza - specjalistów od onanizmu i pedofilii, wpływowych medyków wykorzystujących legitymizacyjną moc własnej dyscypliny do przeformułowania określonych przejawów seksualności i nadania im statusu niekiedy dosłownie śmiertelnego zagrożenia.

30 M. Foucault, op. cit.

31 A. Stein, K. Plummer, I can't even think straight: „queer” theory and the missing sexual revolution in sociology, [w:] Queer Theory/Sociology, red. S. Seidman, Cambridge-Oxford 1996.

32 M. Warner, Introduction, [w:] Fear of a Queer Planet, red. M. Warner, Minneapolis 1993. 
Postępujące unaukowienie różnych dziedzin ludzkiego życia, a w jego obrębie medykalizacja, sprawiło, że biomedyczny i normatywny sposób konceptualizacji seksualności osiągnął na jakiś czas status hegemona. Można podążać różnymi ścieżkami w poszukiwaniu przemożnych wpływów tego nastawienia ${ }^{33}$. Wiemy jednak, jak cienka jest granica między społecznie konstruowaną diagnozą patologii, choroby psychicznej a buntem, niepodporządkowaniem się wymogom społecznym (normom prawnym, obyczajowym i moralnym). Działania prewencyjno-kontrolne zdają się stanowić epicentrum prób eliminacji tego, co zostało zdefiniowane jako chore i zagrażające. Zakład psychiatryczny może być z łatwością postrzegany jako instytucja totalna. Kaftan bezpieczeństwa (czy to farmakologiczny, czy też materiałowy) jest nie tylko narzędziem obrony przed rzeczywistym zagrożeniem, lecz także ikoną bezwzględnej kontroli i eliminacji niepodporządkowania się. A diagnoza potrafi być (wypracowanym przez medycynę) narzędziem opresji (lub jest to co najmniej jedna z opcji interpretacyjnych). Włącza aktywność seksualną o określonej charakterystyce w zakres stanów kategoryzowanych jako chore i legitymizuje interwencję. Obecne od kilku dekad zmiany w obrębie dominującego dyskursu wokół tej materii oraz historyczno-kulturowe zakotwiczenie współtworzą dystans, dzięki któremu można uznać na przykład, że poglądy Bilza były dziwaczne i zabawne. Jednocześnie pojawia się świadomość tego, że on sam i jemu współcześni (przynajmniej w znacznej liczbie) nie uważali jego książki ani za bzdurną, ani satyryczną. „Wysycenie” dominującym dyskursem sprawiało, że alternatywne konceptualizacje były „nie do pomyślenia” i z pewnością „nie do wypowiedzenia" publicznie.

Nauka, a ściślej rzecz biorąc nauki biologiczno-medyczne, były i są miejscem dokonujących się konstrukcji i rekonstrukcji ludzkiej seksualności w obrębie nowoczesności. Raczej nieprzypadkowo to właśnie raporty Kinseya stanowiły punkt zwrotny w podejściu do studiowania tematu, a nie na przykład doniesienia antropologów kulturowych. Obserwując zaś rekonstrukcje seksualności, nietrudno dostrzec, że niektóre zachowania zostają wyłączone z patologicznych klasyfikacji (na przykład homoseksualizm i masturbacja), a inne są poddane odwrotnemu procesowi. Zachodzącą zmianę można zaobserwować między innymi porównując starsze teksty naukowe $\mathrm{z}$ nowszymi ${ }^{34}$. Na ich podstawie potrafimy też wskazać

33 Szukając odzwierciedlenia ówczesnej hegemonii i jej pokłosia, można na przykład studiować język używany w publikacjach na ten temat. Zawarte w nich słowa klucze (takie, jak zbuntowany onanizm, prewencja, kontrola, zakład psychiatryczny, nimfomanki, kajdanki, specjaliści itp.) w pewnym sensie tworzą elementy sieci, w którą usiłuje się schwytać niepożądane zachowania. Posługiwanie się zaś nazwami różnych specjalności uświadamia, że w zwalczaniu specyficznych zachowań biorą również udział inne subdyscypliny, niekojarzone wprost ze specyficznym problemem lub wręcz jawiące się jako niemające z nim nic wspólnego.

34 Sobiectwo lub homoseksualizm są ciekawymi materiałami do studium rekonstrukcji społecznej, dyskursywnej dialektyki, której jedną z głównych dynamik stanowi medycyna i medykalizacja. Studiowanie prac na ten temat uświadamia między innymi, jaki ogrom pracy został wykonany pod egidą nauki, której celem było wytworzenie społecznego przekonania, że homoseksualizm 
niektórych „rekonstruktorów” dokonujących zmian i legitymizujących je. Wśród nich są Havelock Ellis ${ }^{35}$ i Zygmunt Freud ${ }^{36}$, a nieco później wspomniany Alfred Charles Kinsey oraz William Howell Masters i Virginia Eshelman Johnson ${ }^{37}$. Ich rekonstrukcje obowiązującego dyskursu mogą z jednej strony wzbudzać podziw,

jest chorobą wymagającą leczenia tak samo, jak trąd i gruźlica; czasem syzyfowej, jak wtedy, gdy Rada Nadzorcza Amerykańskiego Towarzystwa Psychiatrycznego (The Board of Trustees of the American Psychiatric Association) przegłosowała usunięcie homoseksualizmu z DSM (Diagnostic and Statistical Manual of Mental Disorders - klasyfikacja zaburzeń psychicznych Amerykańskiego Towarzystwa Psychiatrycznego) w 1973 roku. Decyzja została ratyfikowana po referendum, w którym wzięło udział 10091 osób i 58\% z nich optowało za reklasyfikacją (G. Mendelson, Homosexuality and psychiatric nosology, „Australian and New Zealand Journal of Psychiatry” 37, 2003, s. 678-683). Była ona skutkiem głosowania określonej liczby osób, co uwypukla społeczny charakter konstrukcji diagnozy psychiatrycznej. Co więcej, zwycięstwo tej opcji może być określone jako niejednoznaczne. Owa niejednoznaczność pogłębia się, gdy przypomnimy, że w ICD (International Statistical Classification of Deseases and Related Health Problems - Międzynarodowa klasyfikacja chorób, obowiązująca w Polsce) depatologizująca homoseksualizm reklasyfikacja nastąpiła w 1992 roku. Mimo że wielu badaczy seksualności deklaruje, iż „[p]ojęcie zboczenia płciowego zmienia się. To co jest uważane za zboczenia płciowe, w jednym społeczeństwie, części świata czy epoce, może być uważane za normalny przejaw życia seksualnego w innymi społeczeństwie, czasie czy miejscu. Typowym przykładem tego są np. zapatrywania na istotę homoseksualizmu i kazirodztwa w różnych kulturach i na przestrzeni czasu" (Seksuologia kliniczna, red. T. Bilikiewicz, K. Imieliński, Warszawa 1974, s. 197), to we współczesnych publikacjach często mamy do czynienia ze słownictwem mającym wzbudzić reakcje emocjonalne względem seksualnych „potworów” szukających ofiar wśród dzieci i dorastających. Demonizacja stała się niemal regułą. Egzemplifikacją jest dyskurs wokół pedofilii, który uległ radykalizacji (nawet ten naukowy) i nasuwa myślenie w kategoriach paniki moralnej.

35 Zdaniem niektórych badaczy awangardowym reprezentantem „dobrej zmiany” w podejściu do seksualności był Havelock Ellis. Jako pierwszy ogłosił, że masturbacja jest czynnością normalną i prawdopodobnie konieczną składową zdrowego rozwoju chłopców i dziewczynek. Umieścił ludzką seksualność w innym kontekście. W jego perspektywie stała się ona ścieżką ku radości i spełnieniu. Wiele lat wcześniej od Zygmunta Freuda opublikował serię studiów przypadków, które ukazywały szerokie spektrum dziecięcych seksualnych zainteresowań i doświadczeń, wskazał na represję wczesnej seksualności dziewczynek jako przyczynę oziębłości kobiet; uprzedził także Kinseya i Mastersa, opisując męską impotencję i kobiecą oziębłość jako zjawiska o charakterze psychologicznym - por. A. Yates, Sex Without Shame: Encouraging the Child's Healthy Sexual Development, William Morrow edition on the Internet 2001, s. 46.

${ }^{36}$ Zygmunt Freud wtórował Ellisowi w procesie normalizacji ipsacji. Zarazem wytyczył jej nowe granice, reprezentując pogląd, że wprawdzie są to podstawowe czynności wyrażające naszą seksualność, ale trzeba je okiełznać w dorosłym życiu. W dorosłości popęd seksualny powinien być zaspokajany w heteroseksualnym związku małżeńskim.

37 Kolejni badacze, podążając śladem Ellisa i Freuda, między innymi Kinsey, Masters i Johnson, wespół z ruchami feministycznymi i innymi siłami społecznymi doprowadzili do przedefiniowania masturbacji. Przestała być gwałtem na samym sobie, przeistoczyła się w składową samospełnienia, samorealizacji, w wyraz swobody ekspresji seksualnej. Społeczną matrycę percepcji i interpretacji przeformułowano w radykalny sposób. W każdym razie przestano ją postrzegać, przynajmniej w części opiniotwórczych środowisk, jako powód zaburzeń fizycznych i psychicznych, co najwyżej jako źródło zmartwienia i poczucia winy wynikające z internalizacji niepochlebnych wzorców interpretacyjnych. Uznano też, że skoro nie ma zagrożenia, punitywne nastawienie traci sens. 
z drugiej zaś sprawiać wrażenie, że zatracili oni instynkt samozachowawczy. Społeczne „przeróbki” zazwyczaj nie są procesami szybkimi i łatwymi, szczególnie wtedy, gdy dotyczą seksualności i ściśle z nią związanej moralności. Silne reakcje społeczne wzbudza prowadzenie, a jeszcze bardziej upublicznianie, wyników badań nieprzystających do uznawanych standardów zachowań, wyznaczanych przez akceptowane systemy aksjonormatywne i zarazem traktowanych jako naturalne. Raporty Kinseya na pewno należały do tej grupy publikacji naukowych. Prezentowały badania dotyczące zachowań seksualnych Amerykanów (Sexual Behavior in the Human Male, 1948) oraz Amerykanek (Sexual Behavior in the Human Female, 1953) i wzbudziły spory rezonans społeczny. Powodem szerokiego, skandalizującego wręcz odzewu było to, że informowały o dopuszczaniu się nieaprobowanych i dość powszechnie uważanych za niemoralne i nienormalne praktyk seksualnych przez sporą cześć przebadanej populacji. Wyniki ujawniały też, że znaczny procent populacji ma w swoim doświadczeniu seksualnym epizody pedofilskie i homoseksualne, zdrady są częste w związkach małżeńskich (w populacji zarówno mężczyzn, jak i kobiet), a onanizm — powszechny. Badania Kinseya wskazały, że binarny system kategoryzacji orientacji seksualnych jest chybiony, albowiem w rzeczywistości jest to kontinuum. Dodatkowym odkryciem, oburzającym dla wielu kręgów społecznych, była możliwość przemieszczania się jednostki w obrębie tegoż kontinuum. W publikacjach nawiązujących do osób mających w życiu epizody heteroseksualne i homoseksualne Kinsey nie posługiwał się terminem „biseksualizm”. Pierwsze dwa określenia - heteroseksualizm i homoseksualizm — również okazały się uproszczeniem nieodzwierciedlającym rzeczywistości. Najważniejsza była niezwykła płynność w przemieszczeniu się po paśmie preferencji. Dlatego zespół badawczy Kinseya podczas oznaczania seksualności danej osoby o wiele chętniej używał liczb zaczerpniętych ze skonstruowanej przez siebie siedmiopunktowej skali. Zdaniem Kinseya idealny badacz zachowań seksualnych opisałby siebie za pomocą cyfry 3 na skali seksualności, czyli „pośrodku” - pomiędzy homoseksualnością i heteroseksualnością. Dzięki temu mógłby empatyzować $\mathrm{z}$ wieloma badanymi osobami. Współpracownicy dodawali do tego - z przymrużeniem oka - że taki naukowiec powinien być także hermafrodytą... ${ }^{38}$ Jak napisali Brian Dodge, Michael Reece i Paul H. Gebhard, Kinsey unikał wypowiadania się na temat przyczyn orientacji seksualnej, ponieważ jego zdaniem zarówno eksperci medyczni, jak i establishment kościelny nie byli przygotowani na rozważania wokół nieheteroseksualności w kategoriach innych niż defekt i choroba. Co interesujące i intrygujące, biseksualizm nie został nigdy oficjalnie zakwalifikowany ani zdeklasyfikowany jako zaburzenie psychiczne, choć zarazem był „podciągany” pod homoseksualizm. Zdaniem autorów artykułu Kinsey byłby prawdopodobnie zawiedziony faktem, że współczesna emancypa-

38 B. Dodge, M. Reece, P.H. Gebhard, Kinsey and beyond: Past, present, and future considerations for research on male bisexuality. Part I: History and bisexuality, „Journal of Bisexuality” 8, 2008. 
cja dotyczy homoseksualistów, biseksualiści zaś postrzegani są jako nieszczęśliwi, gdyż nie mogą się zdecydować, za którą orientacją się opowiedzieći ${ }^{39}$. Niegdyś można było być tylko „hetero”; obecnie można również być „homo”, ale „bi” nie mieści się ani w jednej, ani w drugiej kategorii i tu pojawia się problem... wynikający z potrzeby upraszczania rzeczywistości.

Bez względu na „zamieszanie”, jakie wywołały raporty Kinseya, ujawniające niewygodne informacje dotyczące seksualności Amerykanów, a może dzięki nim, następowały zmiany w postrzeganiu seksualności. Proces ten wspomagały między innymi prace badawcze i publikacje Mastersa i Johnson, które doprowadziły do umieszczenia wielu zachowań seksualnych w nowych ramach odniesienia. Odium, jakim były obciążone, zaczęło znikać; miejsce po nim zaczęły wypełniać inne sposoby widzenia tej kategorii zachowań. Pokłosiem przeformułowań w paradygmacie medycznym jest włączenie „sobiectwa” i „tobiectwa” do technik terapeutycznych. Znani i uznani psychologowie i psychiatrzy, specjalizujący się psychoterapii dysfunkcji seksualnych, zalecają pacjentom i pacjentkom określone sposoby stymulowania siebie i partnera. Helen Singer Kaplan była jedną z prominentnych terapeutek, która korelowała unikanie autostymulacji i nieumiejętność koncentracji na fantazjach oraz obrazach erotycznych $z$ dysfunkcjami seksualnymi (w tym anorgazmii) ${ }^{40}$. W Polsce podkreślany jest wkład, jaki wniosła Michalina Wisłocka w normalizację części praktyk seksualnych, które - jak wynika z prezentowanego cytatu - społecznie były różnie oceniane. W książce wydanej w 1988 roku można przeczytać:

Wreszcie dziesięć lat temu spróbowałam w artykule umieszczonym w czasopiśmie „Kobieta i Życie” napisać coś niecoś o leczniczym znaczeniu onanizmu u kobiet w wieku przekwitania. Oczywiście, jak zwykle, sypnęły się obelżywe listy protestujące. Ale równocześnie, ku ogromnemu mojemu i redakcji zdziwieniu, przyszło znacznie więcej listów od kobiet samotnych, dziękujących mi za poruszenie tej sprawy. Jak wynikało z listów, wiele kobiet uprawiało onanizm $\mathrm{w}$ wielkiej tajemnicy, z ogromnym poczuciem winy, uważając, że są nienormalne ${ }^{41}$.

\section{Dorota Majka-Rostek, Pawet Czajkowski, Robert Florkowski}

\section{Bibliografia}

Baudrillard J., Społeczeństwo konsumpcyjne. Jego mity i struktury, przeł. S. Królak, Warszawa 2006. Baudrillard J., Symulakry i symulacja, przeł. S. Królak, Warszawa 2005.

${ }^{39}$ Ibidem.

${ }^{40} \mathrm{~W}$ jej pracy można znaleźć wiele opisów odmian samostymulacji. Czasami pacjentka jest zachęcana do ćwiczenia tej umiejętności w samotności, kiedy indziej w towarzystwie partnerki czy partnera. Anorgastyczne kobiety zachęcane są do rozbudzania w sobie umiejętności radosnej, odhamowanej zabawy własnym ciałem - H.S. Kaplan, Disorders of Sexual Desire and Other New Concepts and Techniques in Sex Therapy, New York 1979.

${ }^{41}$ M. Wisłocka, Sztuka kochania w dwadzieścia lat później, Warszawa 1988, s. 207-208. 
Baudrillard J., O uwodzeniu, przeł. J. Margański, Warszawa 2005.

Berger P., Luckmann T., Społeczne tworzenie rzeczywistości, przeł. J. Niżnik, Warszawa 2010.

Bourdieau P., Męska dominacja, przeł. L. Kopciewicz, Warszawa 2004.

DeLamater J.D., Hyde J.S., Essentialism vs. social constructionism in the study of human sexuality, "Journal of Sex Research" 35, 1998, nr 1, s. 10-18.

Dodge B., Reece M., Gebhard P.H., Kinsey and beyond: Past, present, and future considerations for research on male bisexuality. Part I: History and bisexuality, „Journal of Bisexuality" 8, 2008, s. $175-189$.

Elias N., Przemiany obyczajów w cywilizacji Zachodu, przeł. T. Zabłudowski, K. Makarewicz, Warszawa 1980.

Foucault M., Historia seksualności, przeł. B. Banasik, T. Komendant, K. Matuszewski, Gdańsk 2010. Jetha C., Ryan Ch., Na początku był seks. Prehistoryczne źródła nowoczesnej seksualności, przeł. A. Patrykowska, Warszawa 2012.

Kaplan H.S., Disorders of Sexual Desire and Other New Concepts and Techniques in Sex Therapy, New York 1979.

Kaufmann J.-C., Niezwykła historia szczęśliwej miłości, przeł. A. Kapciak, Warszawa 2012.

Kinsey A.C., Pomeroy W.B., Martin C.E., Sexual Behavior in the Human Male, Philadelphia 1948.

Kitsuse J.I., Societal Reaction to Deviant Behavior: Problems of Theory and Method, „Social Problems" 9, 1962, s. 247-256.

Lorber J., Beyond the binaries: Depolarizing the categories of sex, sexuality, and gender, „Sociological Inquiry" 66, 1996, s. 143-160.

Luhmann N., Semantyka miłości. O kodowaniu intymności, przeł. J. Łoziński, Warszawa 2003.

Macintosh M., The homosexual role, „Social Problems” 1968, nr 16/2.

McNair B., Seks, demokratyzacja pożądania i media, czyli kultura obnażania, przeł. E. Klekot, Warszawa 2004.

Mendelson G., Homosexuality and psychiatric nosology, „Australian and New Zealand Journal of Psychiatry" 37, 2003, s. 678-683.

Plummer K., Queers, bodies and post-modern sexualities: A note on revisiting the „sexual“, „Qualitative Sociology" 2003, nr 26 (4), s. 515-530.

Rubin G.S., Rozmyślając o seksie: zapiski w sprawie radykalnej teorii polityki seksualności, „Lewą Nogą" 2004, nr 16, s. 164-224.

Seidman S., Społeczne tworzenie seksualności, przeł. P. Tomanek, Warszawa 2012.

Seksuologia kliniczna, red. T. Bilikiewicz, K. Imieliński, Warszawa 1974.

Simmel G., Psychologia kokieterii, [w:] idem, Most i drzwi, przeł. M. Łukasiewicz, Warszawa 2006, s. 231-247.

Simmel G., Socjologia, przeł. M. Łukasiewicz, Warszawa 2005.

Szanter S., Socjologia kobiety, Warszawa 1948.

Szlendak T., Architektonika romansu, Warszawa 2002.

Szlendak T., Supermarketyzacja. Religia i obyczaje seksualne młodzieży w kulturze konsumpcyjnej, Wrocław 2004.

Weeks J., Sexuality, London 1986.

Wisłocka M., Sztuka kochania w dwadzieścia lat później, Warszawa 1988.

Yates A., Sex Without Shame: Encouraging the child's healthy sexual development, William Morrow edition on the Internet 2001. 